\title{
How often do follow-on activities occur - trends seen in a patent database for GPCRs
}

\author{
Christian Tyrchan ${ }^{1 *}$, Sorel Muresan ${ }^{2}$ \\ From 7th German Conference on Chemoinformatics: 25 CIC-Workshop \\ Goslar, Germany. 6-8 November 2011
}

The first compound reaching the market following the approval of the official offices is referred to as first-inclass or breakthrough drug. These compounds constitute a new class of drugs meaning that they introduce a novel mode of action (MoA) or provide a significant improvement over the standard therapy, if not enables a therapy, in terms of efficacy and safety. A follow-on (or me-too) drug is, in the common understanding, a chemical entity which has structural similarity or has the same pharmacological MoA as the first-in-class drug. The approach of follow-on drugs is controversially discussed in the literature [1-3].

Based on the GVKBIO Medicinal Chemistry and Target Class databases (which capture explicit relationships between published documents, compounds, assay results and targets), we investigated the occurrence of drug discovery follow-on activities as captured by the pharmaceutical patent space [4]. To do so, we abstracted from the GVKBIO databases 11,827 patents which are linked to a GPCR target with a defined Entrez Gene ID (as November 2010). In a next step, we removed all peptide structures because of the size and the similarity of their backbone. Subsequently, we kept all 10,253 patents belonging to the TOP 100 companies in terms of number of patents published. The set was consolidated by merging patents for known mergers and acquisitions until 2008. All possible patent combinations were created if they share an official gene name and are published by different companies within a 6-year interval. Similarity descriptors and scores could be generated for $1,570,381$ out of a total of 1,608,368 pairs (97.6\%) [5].

As expected, the pharmaceutical research is highly competitive and dynamic. This is supported by the fact that most of the follow-on patents are published within

\footnotetext{
* Correspondence: christian.tyrchan@astrazeneca.com

${ }^{1}$ AstraZeneca R\&D, CVGl iMed, Pepparedsleden 1, S-43183 Mölndal, Sweden Full list of author information is available at the end of the article
}

the first two years with a high number of patent pairs published in the same year. Around 4800 (47\%) patents included in our analysis are linked to follow-on activities with only small differences between the companies.

\section{Author details}

${ }^{1}$ AstraZeneca R\&D, CVGl iMed, Pepparedsleden 1, S-43183 Mölndal, Sweden. ${ }^{2}$ AstraZeneca R\&D, DECS, Pepparedsleden 1, S-43183 Mölndal, Sweden.

Published: 1 May 2012

\section{References}

1. Cohen J, Cabanilla L, Sosnov J: Role of follow-on drugs and indications on the WHO Essential Drug List. J Clin Pharm Ther 2006, 6:585-592.

2. Dimasi JA, Faden LB: Competitiveness in follow-on drug R\&D: a race or imitation? Nat Rev Drug Discov 2011, 1:23-27.

3. Hollis A: Comment on "The economics of follow-on drug research and development: trends in entry rates and the timing of development". Pharmacoeconomics 2005, 12:1187-92.

4. [http://www.gvkbio.com/informatics.html].

5. Godden JW, Bajorath J: Differential Shannon Entropy as a sensitive measure of differences in database variability of molecular descriptors. J Chem Inf Comput Sci 2001, 4:1060-1066.

doi:10.1186/1758-2946-4-S1-P51

Cite this article as: Tyrchan and Muresan: How often do follow-on activities occur - trends seen in a patent database for GPCRs. Journal of Cheminformatics 2012 4(Suppl 1):P51.

\section{Publish with ChemistryCentral and every scientist can read your work free of charge \\ "Open access provides opportunities to our colleagues in other parts of the globe, by allowing anyone to view the content free of charge." \\ W. Jeffery Hurst, The Hershey Company.}

- available free of charge to the entire scientific community - peer reviewed and published immediately upon acceptance

- cited in PubMed and archived on PubMed Central

- yours - you keep the copyright

Submit your manuscript here:

http://www.chemistrycentral.com/manuscript/

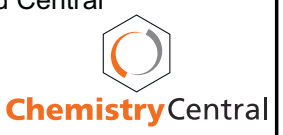

